\title{
Refuge
}

Canada's Journal on Refugees

Revue canadienne sur les réfugiés

\section{The Migrant Passage: Clandestine Journeys from Central America by Noelle Kateri Bridgen}

\section{Kimberly Sigmund}

Volume 35, Number 2, 2019

Private Sponsorship in Canada

URI: https://id.erudit.org/iderudit/1064824ar

DOI: https://doi.org/10.7202/1064824ar

See table of contents

Publisher(s)

Centre for Refugee Studies, York University

ISSN

0229-5113 (print)

1920-7336 (digital)

Explore this journal

Cite this review

Sigmund, K. (2019). Review of [The Migrant Passage: Clandestine Journeys from Central America by Noelle Kateri Bridgen]. Refuge, 35(2), 123-124.

https://doi.org/10.7202/1064824ar 


\title{
Book Reviews
}

\author{
The Migrant Passage: Clandestine Journeys from Central America \\ n \\ Noelle Kateri Bridgen \\ Ithaca, NY: Cornell University Press, 2018, 264 pp.
}

$\mathrm{I}$ $\mathrm{n}$ The Migrant Passage: Clandestine Journeys from Central America, Noelle Kateri Bridgen beautifully blends theories and methodologies from international relations (IR) and anthropology to present an ethnography spanning the 4,500 kilometres between El Salvador and the U.S.-Mexican border. Bridgen weaves together migrant narratives and analysis of national policies to call attention to the dangers of the migration trail through Mexico and to illustrate how migrants attempt to avoid these dangers. The major theoretical contribution of the book lies in how it engages practices of "improvisation" - those of the migrants and the people they attempt to avoid along their journey.

The book is laid out in three "acts": Exposition, Rising Action, and Climax. This clever layout aids the reader in understanding Bridgen's overarching point: that the act of migrating from Central America to the United States through Mexico is a constantly shifting improvisational play, being performed over and over again by migrants and the people they encounter along the route; and that these improvisations and interactions are constantly being shared, secreted away, and reinterpreted in ways that change not only the concept of migration through Mexico, but also the actual landscape over which the migrants must travel to stay ahead of immigration enforcement, gangs, and cartels.

Bridgen lays the groundwork for the reader in act 1, chapter 1, by introducing the migrants with whom she worked and the map-making exercise that she used to tease out how migrants understand the migration trail. She dubs these maps and the corresponding stories they elicit "survival plays." It is through these survival plays that she demonstrates how ambiguous and shifting the migratory path is, and how each individual migrant has a different idea about how they might get from point A to point B, what they might experience along the journey, and what they see themselves leaving behind and moving towards. In this section of the text she also lays out background research on the social, political, and historical factors that have shaped the current migration process in North and Central America. We learn that alongside globalization and the role of the nation-state in creating borders, migrants have become "unwilling props in the political theater of borders" (18).

In chapters 2 and 3, Bridgen lays out the plot of her ethnography, unpacking migration stories that illuminate the processes through which she sees human mobility occurring. These chapters also outline her methodological and theoretical frameworks, discussing how she mirrored the migration process in order to gather her data, spending two years on the migrant route through Mexico, volunteering in migrant shelters, riding "la Bestia," the freight train that moves people swiftly north while atop its unsafe freight cars, and visiting the hometowns of Salvadoran migrants. Here Bridgen also lays out her conceptual framework, which draws from anthropology and IR. She notes the use of anthropological concepts surrounding flows and clandestine activity, helps to break down false binaries such as mobile/immobile and legal/illegal, and discusses how these concepts fill a gap in the IR literature surrounding transmigration and globalization. She also offers a "disruption of the boundaries of politics" (33) in order to show how unanticipated changes in the state-society relationship are contingent upon each 
other's actions and reactions. In chapter 3 , she explains how ever-changing political shifts in the United States, Central America, and Mexico have shaped the migration journey. These include push-pull factors such as poverty in El Salvador vs. economic opportunity in the United States. These factors have encouraged migration from 1979 to the present day, despite the steady increase in danger for migrants as U.S. and Mexican politics have become less friendly towards migration from the south.

Act 2, which encompasses chapters 4 and 5, discusses the performance of "survival plays" on the migration trail. Utilizing the survival plays, or survival strategies, of her informants, Bridgen demonstrates how migrants attempt to improvise aspects of their identity such as nationality, race, class, and gender; and what larger effects these strategies have on the social and political scenes in which they are performed. Bridgen had her informants draw maps so she could better understand "the construction of the social imagination of the route" (149). Through this exercise she teases apart ideas about the transit political economy and how migration has changed local cultures and the legal economy. She ends by discussing how helpful visualizations of the migration route can be for researchers who desire a way to understand, and thereby advocate for, vulnerable populations.

In act 3, the climax and conclusion, Bridgen describes the tragedy of migration for the many migrants who are caught between their homes, the transit route, and their destination. These "permanent wanderers" offer a cautionary tale to politicians and the proponents of neo-liberalism about the real risks, to both the imagined boundaries of the nation-state and to the lives of transnational migrants, posed by current migration policies. She argues that the "sovereign stagecraft of policymakers" can no longer ignore the humanity of migrants, as people and cultures continue to move across transnational spaces in defiance of the borders that nationstates so forcefully continue to uphold.

Bridgen's fascinating account of the improvisations that are formed by and help form the migration route through Mexico sheds light on the motivations behind migration, the increasing dangers of the migration journey in North America, and the role the United States has played in the political turmoil in Central America that pushes many migrants to face the journey north. Likewise, she explains how the "blind eye" approach to immigration practices that Mexican officials take denies human rights protections to migrants travelling within their borders who face violence at the hands of drug cartels, the Mexican police, and immigration enforcement. This ethnography would be an excellent addition to anthropological courses on Latin America, cultural anthropology, and migration studies, and would be a superb resource for shifting the sights of international relations towards a more grounded understanding of the socio-political factors of migration that shape and are shaped by globalization, global politics, and neo-liberalism today.

Kimberly Sigmund is a PhD researcher in the Anthropology Department at the University of Amsterdam. The author may becontacted at k.r.sigmund@uva.nl.

\section{Forging African Communities: Mobility, Integration and Belonging}

Edited by Oliver Bakewell and Loren B. Landau

London: Palgrave Macmillan, 2018, 321 pp.

$\mathrm{T}$ hrough human mobility, identities and communities are forged. This is the central message of Forging African Communities, and the editors use the metaphor of the "forge" deliberately, playing with the word's double meaning. First, to forge is to build or create, "transform[ing] ... existing material into new, potentially unrecognizable forms that nonetheless build on past histories" (3). This sense highlights the emergence of new possibilities, while also acknowledging the continued importance of what came before. But to forge is also to fake, falsify, and misrepresent-actions that, the editors argue, are "often central to migrants' experiences and strategies" (4). Both senses of the metaphor imply agency: as they move across multiple sites and scales, people actively make and remake communities and themselves.

This edited volume presents pieces from scholars across a variety of disciplines-including development studies, demography, sociology, and anthropology-that illustrate community building and self-making through mobility in African contexts. Africa, the editors suggest in their introduction, holds particular relevance for this kind of exploration 